DOI: 10.22559/folklor.981

folklor/edebiyat, cilt:25, sayı:99, 2019/3

\title{
Sanal Dünyada Halk Mizahının Gülen/Güldüren Yüzü: Siyasi Fıkralar
}

\author{
Smiling Face of Folk Humor in the Virtual World: \\ Political Anecdotes
}

\section{Mehmet Emin Bars*}

$\ddot{\mathbf{O} z}$

Yeryüzünde bilim ve teknoloji her geçen gün büyük bir hızla yenileşmeye, değişmeye devam etmektedir. Bu değişimler olumlu veya olumsuz biçimde insan hayatını da etkilemektedir. Teknolojik hayattaki değişimler kültürel değişimleri de zorlamakta, yenileşmelere bağlı yeni kültürel alışkanlıklar doğurmaktadır. İnternet özellikle son yirmi yılda kültürel değişmeleri meydana getiren en önemli araçlardan biri haline gelmiştir. Sözlü ve yazılı kültür ortamlarında daha yavaş meydana gelen kültürel değişimler, elektronik kültür ortamında büyük bir hız kazanmıştır. Değişimle birlikte yeniden oluşan gelenekler çok daha geniş bir izleyici/dinleyici kitlesine ulaşmaktadır. Folklor (halk bilimi) da bu değişimlerden etkilenmiş, araştırma alanını genişletmiş, yeni ve zengin bir inceleme alanı bulmuştur. Folklor türlerinden fikra, her dönemde insanları güldüren, düşündüren bir tür olarak toplumda önemli bir yer tutmuştur. Uzun süre sözlü, sonrasında yazılı, günümüzde ise öncekilerle beraber elektronik kültür ortamında varlığını sürdüren fikra; yeni icra ortamında önemli fonksiyonlar taşımaktadır. Fıkralar insanla ilgili her türlü konuyu işlemektedir. Bu konulardan biri de insanları, toplumu idare etme, toplumsal ilişkileri düzenleme sanatı olan siyasettir. Siyaset aynı zamanda fikralarda

Doç. Dr., Bingöl Üniversitesi, Fen-Ed. Fak. TDE Bölümü mebars@bingol.edu.tr 
en fazla işlenen konulardandır. Bu çalışmanın amacı siyasi fıkraların elektronik kültür ortamındaki işlevlerini ortaya koymaktır. Bu amaçla çok sayıda internet sitesi incelenmiştir. Çalışma elektronik ortamdaki siyasi fikralarla sınırlandırılmıştır. Sonuçta siyasi fikraların yeni bağlamda hem geleneği sürdürdüğü hem de yarattığ1 yeni ürünlerle dönüştürdügü görülmüştür. Elektronik kültür ortamı zengin bir fikra arşivi niteliğindedir. Fıkralar güçlü tenkit, ince mizah, hikmetli söyleyişlerini sanal âlemde etkili biçimde sürdürmektedir. Sanal âlem, halk bilimi uzmanları için geniş ve zengin bir araştırma alanı oluşturmaktadır.

Anahtar sözcükler: fikra, siyaset, halk, mizah, elektronik kültür

\begin{abstract}
Science and technology on earth are renewing with greater speed. Innovation also provides change. These changes affect human life either positively or negatively. Changes in technological life also force cultural changes. New cultural habits are emerging due to renovations. The internet has become one of the most important tools for cultural changes especially in the last two decades. Cultural changes that occur more slowly in oral and written cultural environments have gained a great momentum in the electronic cultural environment. Change has created new traditions. these traditions reach a much wider audience/ listener. Folklor is also affected by these changes. Folklor expanded the research area and found a new and rich research area. Anecdote is one of the most important folkor genres. In all periods, the anecdote makes people laugh, think. The anecdote continued to exist in society for a long time, both orally and in writing. Today, the anecdote carries important functions in the electronic culture environment which is the new performing environment. The anecdotes deal with all matters of human interest. One of these issues is politics. Politics is the art of managing people/society and organizing social relations. Politics is also one of the most discussed topics in the anecdotes. The aim of this study is to reveal the functions of political anecdotes in the electronic culture environment. For this purpose, many websites have been examined. The study is limited to political anecdotes in the electronic environment. As a result, it has been seen that political anecdotes in the new context both continue the tradition and transform it with new products. The electronic culture environment is a rich anecdote archive. The anecdotes continue their powerful criticism, subtle humor, wise sayings effectively in the virtual world. The virtual world is a large and rich area of research for folklore specialists.
\end{abstract}

Keywords: anecdote, politics, public, humor, electronic culture

Bir nükte, bazen önemli meseleleri ciddilikten daha tesirli ve mutlu çözer.

(Horace) 


\section{Giriş}

İnsan nüfusunun her gün artması, toplumsal yaşamı düzenleme zorunluluğunu getirmiştir. İnsanların topluluk halinde bir arada yaşamaya başlamalarıyla toplumu kimlerin, nasıl idare edeceği ile ilgili fikirler ortaya atılmıştır. Bu düşünceler siyasi teşkilat olan "devlet" olgusunun ortaya çıkmasıyla bir anlam kazanmıştır. Kalabalıkların işlerini düzene koymak, onları idare etmek, iyi toplum/yaşam arama faaliyetleri "siyaset" terimiyle ifade edilmiştir. Siyaset eski çağlardan itibaren insanların yaşamında önemli bir yer tutmuştur. Devletin/toplumun idaresi ile ilgili tüm faaliyetler siyaset olarak kabul edilmektedir. Siyaset ile iktidar arasında yakın bir ilişki vardır. Nitekim siyaset "iktidar etme, iktidarı kullanma ya da iktidarı kullanmaya katılma çabası”" (Elaltuntaş, 2018: 9)'dır.

Her insanın yaşadığı ülkeyi kimin, nasıl yönettiği ile ilgili bir düşüncesi vardır. "Toplumlarda yöneten ve yönetilenler olduğu müddetçe yönetilenlerin, kendilerini yönetenler ve yönetim biçimi hakkında konuşmaları, beğendiklerini övmeleri, beğenmediklerini yermeleri doğaldır. Bu anlamda, asıl amacı topluma hizmet olan ve aynı zamanda toplumun bir aynası olan siyaset kurumu, her zaman eleştirilerin merkezindedir" (Akyüz, 2009: 93). Siyaset kurumunun varlığı ve hayatını sürdürmesi halka bağlı olduğundan toplumdan soyutlanamaz. Bu bakımdan siyaset, toplumun istek ve ihtiyaçlarına göre şekillenmektedir. Toplumun siyaset kurumundan beklentileri ile siyasetçilerin bu talepler karşısındaki tutumları ahlaki tartışmaları beraberinde getirmiştir.

Devlet, toplumsal düzeni sağlamak amacıyla egemen olan siyasi otoritedir. Siyaset, devlet denen siyasi otoriteyi halkın güvenliği/iyiliği için kullanmadır. Gücü elinde bulunduran, toplumu idare eden, onu daha iyiye/güzele götürme görevi üstlenen kişilerin zaman zaman kendi çıkarlarını halkın çıkarları üzerinde tuttukları görülmektedir. Halkı şahsi istek ve arzulara göre idare etme, mutlak/tek güç olarak her şeyi yapma hakkına sahip olduğunu düşünme, despotik ve adaletsiz uygulamalar bireysel ahlakın yanı sıra "siyasi/siyasal ahlak" kavramının ortaya çıkmasını sağlamıştır. Siyasal ahlak, devlet/ülke idaresinde yöneten ve yönetilenlerin uymaları gereken ilkeler, kurallardır. Bir siyasetçi kendisinin yanı sıra yaşadığı toplumdan da sorumludur. İnsanlar arasındaki sorunları çözmek için ortaya çıkan siyaset, bazen daha büyük sorunların doğuşuna neden olmuştur.

Toplum içerisinde yaşayan insanların birbirlerine karşı görev ve sorumlulukları olduğu gibi devlet de kamu düzenini sağlama konusunda topluma karşı sorumludur. Devlet bu sorumluluklarını yerine getirirken insanlar arası ilişkilerden uzak, sadece kurallara uygun bir biçimde davranmaz. Aksi halde daha büyük problemlere neden olabilir. "Bu sebeple siyasal düzende de bir ahlaki değer yapısının varlığına ihtiyaç duyulur. Bu da siyasal bir ahlakı yani devlet ahlakını zorunlu kılar" (Ayık, 2016: 9-10). Siyasal ahlak, devlet işlerini yürüten kimselerin davranış şekillerini belirtmektedir. Siyasetçilerin toplum idaresinde ahlaken iyi olanı yapması, siyasal mekanizmanın işleyebilmesinin de temel şartlarından birini oluşturmaktadır.

Günümüz modern toplumlarında siyaset, siyasal partiler etrafında sürdürülmektedir. Siyasal partiler de varlıklarını sürdürmek için kendilerine ait kültürel gelenekler meydana getirir. Bu bakımdan siyasetin ve siyasi partilerin anlaşılması "ilgili parti üyelerince paylaşılan tutum, davranış, alışkanlık ve kabuller” (Özdemir, 2002: 56)'den meydana gelen siyasal kültürün bilinmesine bağlıdır. Siyasal parti liderleri, siyasal parti değer ve yargılarını kendi 
kişiliklerinde sergileyebilen kişilerdir. Bir siyasi parti, içinde bulunduğu toplum veya grubun kültürünü yansıtabildiği ölçüde toplum tarafından kabul edilebilir. Kültür, insanlar arasındaki iletişimin bir ürünüdür. "Bu bağlamda siyasal parti kültürü, parti üyeleri arasındaki ilişki ve iletişimin bir ürünüdür. Diğer taraftan da oluşturulan kültür, parti üyelerinin ilişki ve iletişim biçimini de belirler" (Özdemir, 2002: 58). Toplumu yönetme gücünü elinde bulunduran siyasetçiler, toplum kültürünü de yönlendirip biçimlendirmektedir.

Türklerde millet ile devlet birbirini tamamlayan, ayrılmaz iki parça olarak düşünülmüştür. Kafesoğlu (2012: 239), üç türlü hükümranlık şeklinden söz eder: Gelenekçi hakimiyet, karizmatik hakimiyet, kanuni hakimiyet. Eski Türk hükümranlık telakkisi "karizmatik tip" olarak kabul edilmektedir. Bu tip hükümranlıkta hükmetme yetki ve kudreti, tanrısal kaynaklıdır. Türk hükümdarına idare etme yetkisi, Tanrı tarafından verilmiştir. Türk Bilge Kağan “Tanrı gibi (ve) Tanrıdan olmuş" (Tekin, 2010: 21)’tur. O, ilahi bir misyonu yerine getirmek için bizzat Tanrı tarafından tahta oturtulmuştur: “...babam hakanı (ve) annem hatunu yüceltmiş olan Tanrı, devlet veren Tanrı, Türk halkı(nın) adı sanı yok olmasın diye, beni o Tanrı hakan (olarak tahta) oturttu" (Tekin, 2010: 31). Hükümdara verilen "kut" ona sorumluluklar getirmektedir. Halka karşı görevini yerine getirmeyen hükümdarın kutu, Tanrı tarafından alınır. Hükümranlık, töreye göre icra edilir. Bu yönüyle esasları kanunlarla tespit edilen kanuni hakimiyetin de töre ile sağlandığı görülmektedir. Hükümdar, işlerinde istişare etmek, meclisin onayını almak zorundadır. Eski Türklerdeki hükümdar-halk ilişkisinin etkileri, günümüz Türk siyaset kurumunda görülmektedir. Toplumsal hafıza eskiye ait kültürel unsurları değiştirerek/dönüştürerek, günümüze uyarlayarak varlığını sürdürmektedir.

$\mathrm{Bu}$ çalışmada elektronik kültür ortamında yer alan siyasi (politik) fikralar ele alınacaktır. Folklorun diğer ürünleri gibi fikralar da bağlam değişikliğine bağlı olarak yer aldığı yeni kültür ortamında yeni niteliklerle karşımıza çıkmaktadır. Sözlü kültür ortamının üzerinde en fazla araştırma yapılan, toplumun mizahi ve hikmet özelliğini etkili biçimde yansıtan türlerden biri olan fikralar; sözlü ve yazılı kültür ortamlarındaki niteliklerinde birtakım değişim/ dönüşümler geçirmiş, elektronik kültür ortamında yeniden üretilmiştir. Günümüzde siyaset kurumunun toplumsal yapı üzerindeki etkisi, dönemin tüm topluluklarında etkin biçimde görülmektedir. Tüm kişi ve kurumlarda olduğu gibi siyaset kurumu da fikralarda üzerinde durulan konulardan biridir. Halkın doğrudan ulaşamadığı siyaset ve siyasetçilere dilek ve taleplerini ilettiği en etkin araçlardan birini fikralar oluşturmuştur. Fıkralarda halkın siyasete ve siyasetçilere karşı düşüncelerinin yanı sıra halkın kendi eleştirisini de görmek mümkündür. Bu bakımdan elektronik kültür ortamının siyasal fikralarının ele alınması siyaset kurumunun ve halkın ahlaki tutumunun ortaya konması bakımından önem taşımaktadır. Sözlü ve yazılı kültürün en etkin eleştiri araçlarından biri olan fikralar, elektronik kültür ortamında da bu işlevini sürdürmektedir.

Elektronik kültür ortamında birçok sitede hemen her konu/kişi ile ilgili binlerce fikra bulunmaktadır. $\mathrm{Bu}$ yönüyle elektronik ortam, halk biliminin yeni ve zengin bir araştırma alanıdır. İnternet folkloru (netlore), halk bilimi araştırmacıları tarafından "netnografi” adı verilen yöntemle incelenmeyi beklemektedir. Bu çalışmada "sanal etnografi” olarak da adlandırılan "netrografi" yöntemi kullanılmıştır. Netrografi, sanal toplulukların incelenmesi için 
kullanılan tekniklere verilen addır. Çalışmamızda bilgisayar aracılığıyla sosyal iletişim kuran çevrim içi topluluklardaki siyasi fikralar incelenmiştir. Çevrim içi topluluklar bir topluluğun üyeleri olarak ortak bir amaç etrafında bir araya gelmiş, aralarındaki iletişim belli kural ve düzenlemelerle yeni bir gelenek oluşturmuştur. Çalışma, sanal çevrede bulunan internet topluluklarının siyasetle ilgili fikralarıyla sınırlandırılmıştır. Ancak yeri geldiğinde mevcut fıkralar, sözlü ve yazılı kültür ortamında yaratılan/yaşatılan fıkralarla karşılaştırılarak değerlendirilmiştir.

\section{Halk mizah ve hikmetinin sözcüsü olarak fikra}

F1kra sözlü geleneğin en etkili türlerinden biridir. F1kra günlük konuşmaların yanında birçok anlatım türünün de duygu ve düşünceleri en etkin biçimde vurgulamak için başvurduğu türdür. Fıkranın gerçek hayat sahneleri ile ilgisi, insan ve toplumla ilgili her türlü konunun içinde yer almasını sağlamıştır. Fıkra gerçek yaşantımızla karşılaştığımız "çarpıklıkları, gülünç durumları, tezatları, eski/yeni çatışmalarını ince bir mizâh, hikemî bir söyleyiş, keskin bir istihza ve güçlü bir tenkit” (Yıldırım, 1998: 222) anlayışıyla sunan kısa bir türdür. Her fıkra bir olay (hikâye) anlatır. Yaşanmış veya yaşanması mümkün bütün hayat sahnelerini konu edinir. İnsan-toplum biçimlerinin mizahi açıdan ele alındığı fikralar, belli bir tipin etrafinda meydana gelmektedir. Anlatılmak istenen düşünce, verilmek istenen mesaj tipler aracılığıyla dinleyicilere ulaştırılır. "Hiciv ve tenkit" fikranın nevini tayin edici özelliktir (Boratav, 2017: 303).

F1kraların kısa ve etkin anlatımları, akılda kolayca kalabilen nesir yapıları, mizah ve hicivle kaplanmaları onların toplum içerisinde hızla yayılmasını sağlamıştır. Sözlü geleneğin önemli ürünlerinden olan fikraların XVI. yüzyıldan itibaren "letâifnâme" adıyla yazma mecmualarda varlığı bilinmektedir. Özellikle matbaanın gelişiyle beraber fikraların toplanıp basılması hızlanmıştır. Cumhuriyetin kuruluşundan sonra da fikraların toplanıp yayımlanması devam etmiştir.

İnsanlar sohbetlerini renklendirmek, öğretmen dersini daha iyi anlatabilmek, siyasetçi nutkunu etkili kılmak için fıkraları kullanmaktadır. Fıkralar, içinde taşıdıkları güldürü unsuruyla, iletilmek istenen mesajın muhatabına kolay ulaşmasını sağlarken, tenkit ve istihzanın yumuşak biçimde karşılanıp dinleyicilerin sert tepki göstermelerini engellemektedir. F1kralar özellikle gazete, mecmua ve elektronik iletişim araçlarının bulunmadığı dönemlerde halkın tenkit ve hiciv ihtiyacını karşılamıştır. Gülme, düşündürme, tenkit etme esaslarına dayanan fikralar, az sözle çok fikir anlatmaya çalışır.

F1kraların en önemli niteliklerinden biri onların bir tipe bağlanarak anlatılmalarıdır. Aynı tip etrafında çok sayıda fikra toplanmış veya bir tipe bağlı anlatılan fikra başka tiplere bağlanmıştır. Bir fikra tipindeki değişme, toplumun düşünce yapısının değişiminin sonucudur. Fıkra tipi çoğu zaman yaşamış bir kişiye yeni niteliklerin eklenip zenginleşmesiyle meydana gelmektedir. Gerçekte yaşamış bir şahıs, gerçek kimliğiyle fikralarda yer almaz. Bir kişi, fikralarda toplum tarafından kendisine yakıştırılan farklı niteliklerle yeniden yaratılır. Bundan dolayı bir şahıs, gerçekte yaşamış olsa da, fikra tipine dönüşmesi sonucunda o artık 
kendisi olmaktan çıkmıştır. O, halk tarafından yaratılan yeni bir şahıstır. Bu şahıs, gerçek hayatından çeşitli unsurlar taşımakla beraber, asıl karakterini halk muhayyilesinden almaktadır. Nasrettin Hoca misali ona kendisine ait olmayan, farklı fikra tiplerine ait hikâyeler de eklenmektedir. Halk yeni bir kimlik yaratmakta, fikraya kaynak olan şahsın öz kişiliği zamanla tamamen unutulmaktadır. Nasrettin Hoca, İncili Çavuş, Bekri Mustafa, Bektaşi tiplerine benzer biçimde doktor, öğretmen, siyasetçi gibi tiplerden de söz etmek mümkündür. $\mathrm{Bu}$ bakımdan incelememizde ele alınan siyasi fikralar halk tarafından yaratılan "siyasetçi tipi"nin halk muhayyilesindeki bazı niteliklerini de vermektedir. Türk milletinin sosyal-siyasi hayatının incelenmesinde, toplum hayatının anlaşılmasında siyasi fıkraların kültür tarihi bakımından büyük önemi vardır.

Fıkralarda bulunan nükte motifleri, toplumun ortak malıdır. Aynı nükte birçok millette farklı şahıslar etrafında anlatılmaktadır. Türk toplumunda Nasrettin Hoca'ya bağlı olarak anlatılan fikralar Fransızlarda Panurge, Araplarda Cuha, Almanlarda Eulenspiegel adı etrafinda toplamıştır (Boratav, 2017: 304). Bu fikra kahramanları insanlığın temel düşüncelerini, hissiyatlarını kendi isimleri etrafında toplamıştır. Fıkra tipleri "doğdukları ve yaşadıkları toplum üyelerinin ortak eğilimlerini temsil ettiği”" (Yıldırım, 1998: 228) oranda tanınıp yayılır. Tiplerin nitelikleri, onları yaratan halk tarafından belirlenir. Halkın tutumlarının değişmesi tiplerin değişmesini, zamana ve mekâna uygun yeni tiplerin oluşumunu beraberinde getirir. Halkın tutumu, değer yargıları bir tipin varlığının devam etmesini sağlar. Bu yönüyle fıkra tipleri, içinde yaşadığı/yaşatıldığı toplumun gözü, kulağı, aklı, kalbidir.

Bir toplumda tutum/davranış, zihniyet farklılıkları nispetinde fikra tipleri farklılaşır. Fıkraların bir kısmı geçmişten günümüze az-çok değiştirilerek gelirken, bir kısmı da yeni durumları ifade etmek üzere yeniden yaratılmaktadır. "Bir kişinin neleri komik bulup bulmayacağı, ne tür fikralara gülüp gülmeyeceği, o kişinin içinde bulunduğu topluma, kültürel yapıya, eğitim düzeyine, yaşına, sosyal statüsüne hatta cinsiyetine bağlıdır ve bu ölçülere göre değişebilir” (Tufan, 2007: 108). Bundan dolayı fikralar, toplumsal bağlamları içerisinde değerlendirilmelidir.

Yıldırım (1998: 223), Türk fikralarını konularına göre üç gruba ayırır: 1. İnanç ve itikatlar; 2. Yönetici ve yönetilenler; 3. Günlük durumlar. Ancak bazı durumlarda bir konunun aynı anda birden fazla grubu içine alabileceği unutulmamalıdır. Yöneten-yönetilen esasında ele alınan bir konu, inanç ve itikatları veya günlük hadiseleri de içerebilmektedir. Çalışmamızda ele alınan siyasi fikralar, yönetici-yönetilen konusu etrafında oluşan fikralardır.

Bir milletin sosyal ve siyasi hayatı ile ilgili birçok olayın fikralara konu edinmesi, tüm toplumlarda sıkça rastlanan olaydır. İdarenin tanrı tarafından verildiği veya güçle ele geçirildiği, babadan oğula bir miras olarak görüldüğü, siyasi iktidarın tek otorite kabul edildiği, eleştiriye kapalı, despot ve cebri yönetimlerden seçimle iş başına gelinen, belli dönemlerde halka gidilen demokratik yapılara kadar her dönemde idare edenlerle edilenler arasındaki ilişkileri ele alan fikralara rastlanmaktadır. Bu yönleriyle fikralar sadece birer edebi tür değil, aynı zamanda bir toplumun sosyal ve siyasi tarihine 1şık tutan belgelerdir. Bu tür fikralar idarecilerin halka bakış açısının yanında, milletin çeşitli sosyal ve siyasi durumlar karşısındaki tavrını göstermektedir. Fıkralar bu nitelikleriyle bir milletin düşünce tarihinin önemli sayfalarından birini oluşturmaktadır. 


\section{Elektronik kültür ortamında hiciv/tenkit aracı olarak siyasi fikralar}

Sanal âlemde en fazla dolaşıma sahip türlerden biri fikralardır. Onlarca internet sitesinde binlerce siyasi fikra örneği bulunmaktadır. Elektronik bağlamda her geçen gün diğer türleriyle beraber siyasi fikraların da arttığı görülmektedir. Bu fikraların bir kısmı sözlü ve yazılı kaynaklardan çeşitli değişikliklerle alınırken, bir kısmı da yeni bağlamda yeniden üretilmektedir. Bir fikra, aynı veya benzer biçimlerde farklı sitelerde yer alabilmektedir. Bazı fikralar aynı olay örgüsü etrafında kişi veya yer isimlerinin değiştirilmesiyle meydana getirilmiştir. Elektronik ortamda genel siyasi olayların anlatıldığg fıkralardan Turgut Özal, Süleyman Demirel, Bülent Ecevit, Tansu Çiller, Yıldırım Aktuna, Erdal İnönü, Recep Tayyip Erdoğan gibi Türk siyasetinde önemli roller üstlenmiş siyasi kişiliklere kadar birçok fikra yer almaktadır.

F1kra sitelerine bakıldığında çoğunun isminde "fıkra" sözcüğü geçmektedir. Siteler fikra ile ilgili çeşitli görsellerle zenginleştirilmiştir. Örneğin "http://www.fikradeposu.com” sitesinin ana sayfasında Türk mizah ustası, evrensel fikra tipi Nasrettin Hoca ile eşeğinin resmedildiği aşağıdaki görsel, sitenin kullanım amacını etkili biçimde sunmaktadır:

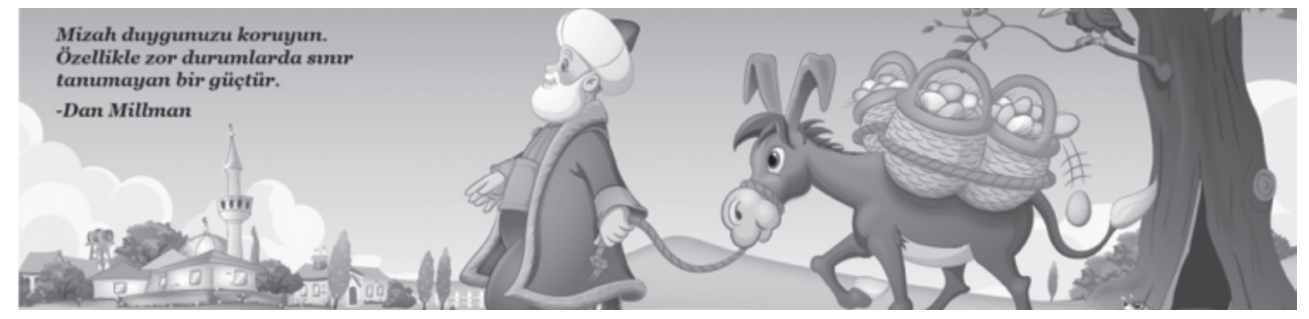

$\mathrm{Bu}$ tür siteler çoğunlukla fikra türlerini kendi içerisinde çeşitli kategorilere ayırmaktadır. Sitede fikralar, alfabetik bir sıra izlenerek konularına göre sınıflandırılmıştır. Kategorilerin başlıkları tıklandığında, konu ile ilgili çok sayıda fıkra karşımıza çıkmaktadır. Fıkralar "meslek, spor, yöre, mezhep/din, millet, ideoloji, ünlü kişiler..." gibi birçok farklı konuyu içermektedir. Arşiv bölümünde, siteye yüklenen fikralar yüklenme tarihlerine göre görülebilmektedir. Fıkralar zaman zaman çeşitli karikatürlerle zenginleştirilmektedir. Sitelerde yer alan "en çok okunan 15 fikra", "en çok önerilen 15 fikra" gibi başlıklar okuyucuları isteklerine göre yönlendirmektedir. Bu sitelere kullanıcılar tarafından kolaylıkla yeni fikralar eklenebilmektedir. Her gün eklenen yeni fikralarla bu siteler birer fikra arşivine dönüşmektedir. Sitelerde çeşitli istatistiki bilgiler de yer almaktadır. Örneğin "http:// fikra.gen.tr/ index.php?sayfa=mektup\&catid=14\&fikra_no=2436" adlı sitede 04.02.2019 tarihi itibariyle yer alan istatistik veriler, bu sitenin folklor açısından ne kadar zengin bir kaynak oluşturduğunu da göstermektedir: Toplam içerik sayısı: 5180, kategori sayısı: 27, okunma sayısı: 209.837.290. Sadece bu sitede yer alan fikraların okunma sayılarına bakıldığında bile elektronik kültür ortamında fikranın sözlü ve yazılı kültür ortamlarıyla kıyaslanamayacak sayıda büyük bir okuyucu kitlesine ulaştığını söylemek mümkündür. Sözlü veya yazılı kültür ortamlarında herhangi bir folklor ürünüyle beraber fikranın, bu derece fazla sayıda bir dinleyici/ okuyucu kitlesine ulaşması zor görünmektedir. Ayrıca sitede çeşitli risk faktörleri oluşturularak "herkes okuyabilir, argo-küfür v.s. içerir, küfür-erotik ifadeler v.s." gibi açıklamalarla okuyucular önceden uyarılmaktadır. 
"Halk" terimi uzun yıllar bağımlı bir yapı olarak tarif edilmiştir. Medeniyetle tezat olarak ele alınan halk, ilkel toplumla medeni toplum arasında yer alan, okuma-yazma bilmeyen cahil kesim olarak medeniyetin kenarlarında yaşayan köylü kavramıyla eşdeğer görülmüştür. Alan Dundes' in “'Halk' terimi en azından ortak bir faktörü paylaşan herhangi bir insan grubunu ifade eder. Bu grubu birbirine bağlayan faktörün -ortak bir meslek, dil veya din olabilir- ne olduğu önemli değildir. Bundan daha önemli olan ise, herhangi bir sebebe bağlı olarak oluşan grubun kendisine ait olduğunu kabul ettiği bazı geleneklere sahip olmasıdır" (1998b: 143) tanımı, halk bilimi (folklor)nin inceleme alanını genişletmiş; onun şehirden köye, okuma-yazma bilenden bilmeyene, her sosyal-kültürel seviyeden en az bir ortak faktörü paylaşan ve bir geleneğe sahip insan topluluğunu inceleyen bilim olarak kabul edilmesini sağlamıştır. Bu tanıma göre, insanların gerçek veya sanal âlemde bir araya gelmesi önemli değildir. Bir internet sitesinde fikralar etrafında bir araya gelen insan topluluğu da halkı oluşturmakta, burada belli kurallar/gelenekler etrafında yapılan tüm sanatsal üretimler de folklorun inceleme alanına girmektedir.

Folklor sadece geçmişin ürünlerini incelemez. Aynı zamanda dinamik bir iletişimsel süreç olarak, içinde yaşanılan zamanın kültürel unsurlarını da inceler. Folklor dinamik yapısıyla, toplumsal değişim/dönüşümlere bağlı olarak, kendisini sürekli yenilemekte; yeni kültürel ortamlarda varlığını canlı biçimde sürdürmektedir. Folklor ürünleri, kendisini bağlamsal değişimlere göre güncellemektedir. "Güncelleme; herhangi bir yaratmanın, içinde bulunulan zamana, dar veya geniş anlamda mekâna ve mevcut sosyoekonomik yapılara uygun hâle getirilmesidir" (Ekici, 2008: 36). Sanal âlemde meydana getirilen fikralar da bulunulan zamana/ mekâna ve sosyoekonomik yapılara uygun biçimde kendisini güncellemektedir. Güncellenen fikralarda, yeni bir yaratmanın yanı sıra, var olanın değiştirilmesi/dönüştürülmesi de söz konusudur. Güncelleme bir geleneğin varlığını sürdürmesinin en önemli araçlarından biridir. Kendisini yeni zamana/mekâna ve sosyal şartlara uygun hale getiremeyen/güncelleyemeyen birçok gelenek yok olup gitmektedir. Her gelenek kendisini güncellerken aynı zamanda gelişir.

“İşlevini yitiren her türlü unsur yok olur.” ilkesine göre birinci sözlü kültür ortamı ürünlerinin bağlamsal değişikliklerle beraber, her geçen gün azaldığg görülmektedir. Elektronik kültür ortamının yaşandığı günümüzde sözlü geleneğin birçok türü, bağlamsal değişimlerle beraber, sanal ortamlarda yerini almaktadır. “... sanal kültür ortamı; sözlü verimlerin korunduğu, icra edildiği, yaygınlık kazandırıldığı hatta çağın getirdiği kültürel imgelere göre yeniden üretildiği ve tüketildiği bir ortama dönüşmüştür" (Aslan, 2011: 40). Halk bilgisi ürünlerinin sözlü olarak nakledilmesi, önemli bir özelliğidir. Ancak tüm halk bilgisi ürünleri bu şekilde nakledilmez. Bu ürünlerin bir kısmı yazılı olarak üretilmektedir. Dundes, halk bilgisi ürünlerinin tarifindeki zorluklardan söz ederken üç seviyeli bir tahlil teklif eder: "Herhangi bir halk bilgisi unsurunu bir kişi dokusu (texture), metni (text) ve onun çevre ve şartları (context) itibariyle tahlil edebilir" (1998a: 108). Doku bir ürünün diline ait özellikleri, konteks ise içinde yer aldığı hususi sosyal durumudur. F1kra türü de bağlamsal değişimlerden etkilenen ürünlerden biri olarak, çeşitli değişim/dönüşümlerle beraber varlığını yeni bağlamlarda sürdürmektedir.

F1kralar sözlü kültür ortamında geleneksel olarak yüz yüze anlatılmaktadır. Destan, masal, halk hikâyelerinin özel anlatıcıları gibi fikraların da özel anlatıcıları vardır. Her insan başarılı, etkili biçimde fikra anlatamaz. Fıkra anlatıcısı bir meddah gibi jest ve mimiklerini kullanarak, kişileri/varlıkları taklit, olayı dramatize ederek anlatır. Anlatıcı, diğer halk an- 
latılarında olduğu gibi, fıkra anlatımında da tavrını dinleyicilerin niteliklerine göre belirler; icrasını buna göre şekillendirir. Yüz yüze iletişimin ortadan kalktığı elektronik ortamda ise anlatıcı, sanal bir mekân içerisinde çoğu zaman kim olduklarını bilmediği çok geniş/farklı niteliklere sahip dinleyici/okuyucu kitleye hitap ederken, ürünü kendi kültürel kodu üzerinden aktarmaktadır. Dinleyici/okuyucu, anlatıcının/yazıcının etkisi olmadan fikrayı anlamlandırmaktadır. Sözlü gelenekte her anlatışta farklı versiyonları/varyantları oluşan fikra, elektronik ortama aktarıldıktan sonra, aradan yıllar geçse de yazılı bir metin haline dönüştüğünden aynı kalabilmektedir. Bu durum her anlatışın yeni bir icra olarak kabul edildiği sözlü kültür ortamı anlatıcısı ve dinleyicisini pasif bir hale dönüştürmüştür.

Halk edebiyatının diğer türlerinde olduğu gibi fikra anlatmak da maharet ve sanat istemektedir. Bir fikrayı yeri ve zamanında etkili biçimde anlatmak, herkesin kârı değildir. Fıkranın seçiminden mizah ve hiciv unsurunu belirtecek edaya, düğümü maharetle çözmekten topluluk üzerinde tesir bırakacak etkiyi yapmaya kadar fikra anlatımı bir usta işidir. Fıkra ustaları “zemin ve zamanı' bilen, fıkrayı yerinde yerleştiren nüktedan, zarif, hoşsohbet, söz sohbeti dinlenir" (Boratav, 2017: 303) kişilerdir. Elektronik kültür ortamında fikra anlatıcısı, yerini internet kullanıcısına bırakmıştır. İnternetin kendisi anlatıcı olurken, takipçiler dinleyici vazifesi görmektedir. Birinci sözlü kültür ortamında bir anlatıcı tarafından yüz yüze anlatılan fikra, sanal ortamda bulunduğu sitenin ziyaretçileri tarafından okunmaktadır. Bilgisayar bir anlatıcı, takipçiler dinleyici konumunda bulunmaktadır. Bu özellik sözlü ortamın canlı fikra anlatıcısını ortadan kaldırmaktadır. Aşağıda geçen fikranın sözlü kültür ortamında usta bir fikra anlatıcısı tarafından belli bir dinleyici kitlesine karşı jest ve mimiklerden yararlanılarak anlatıldığında etkisinin daha fazla olacağı muhakkaktır. Ancak sözlü ve yazılı gelenekte sınırlı sayıda insana ulaşan bu ürünler, elektronik ortamda her yaş, cins, eğitim seviyesine sahip kişi tarafından okunabilmektedir. Ulaştığı geniş kitle ve yayılım hızı düşünüldüğünde, sanal âlem büyük kolaylıklar getirmektedir:

“ABD Başkanı, İngiltere Başbakanı ve Türkiye Başbakanı bir gün bir toplantıda bir araya gelmişler. Tabii, 3 lider bir arada olur da, sormaz mı gazeteciler. Önce ABD Başkanı'na sormuşlar:

- ABD’de bir memur ne kadar parayla geçinir? Siz kaç para veriyorsunuz?

Başkan cevap vermiş:

- Valla ben memura en az 2000 dolar veririm. 1000 doları ile geçinirler. Geri kalan 1000 doları ne yaparlar, nerede harcarlar, hiç sormam.

Gazeteciler aynı soruyu İngiltere Başbakanı'na da sormuşlar. O da cevap vermiş:

- Ben, memuruma ortalama 3000 sterlin veririm. Geçinmesi için 2000 sterlin yeterli. Artan 1000 sterlini ne yapar, nerede harcarlar, sormam, beni hiç ilgilendirmez.

Her ikisinden bu cevapları alan gazeteciler, aynı soruyu bizim başbakana da sormuşlar.

- Valla, demiş bizimki, Türkiye'de bir memurun geçinebilmesi için en az 1 milyar lira lazım. Ama ben taş çatlasın 400 milyon lira veriyorum. Geri kalan 600 milyonu nereden bulurlar, nasıl geçinirler hiç sormam" (https://www.sihirlihikaye.com/siyasi-fikralar.html).

F1kra, Türk siyasetçilerinin halkın sorunlarından haberdar olduklarının; ancak bu sorunlara ilgisiz kaldıklarının ince bir eleştirisini yapmaktadır. 
“F1kralarda zaman, şahıs ve mekân kategorilerinde görülen belirsizlik” (Yıldırım, 1998: 226) onları gerçeklerden uzaklaştırmaz. Bu özellik her şahıs, zaman ve mekânı fikranın içine yerleştirebilmeyi, benzer durumlara uyarlayabilmeyi olanaklı kılmaktadır. Fıkra böylece dinamik bir yapı kazanmakta, insanla beraber yaşamını sürdürmesi sağlanmakta, güçlü bir sosyal-siyasal eleştiri unsuru olabilmektedir. Aşağıdaki Türkiye Cumhuriyeti’nin ikinci cumhurbaşkanı İsmet İnönü’nün dönemini konu edinen ilk fikra, sonraki dönemlerde kendisini güncellemiş; nüfusun 70 milyona ulaştığı bir dönemde belli bir isme bağlı olmaktan çıkarılarak genel bir siyaset eleştirisine dönüştürülmüştür:

"Rahmetli Osman Bölükbaşı ile İsmet Paşa bir uçak yolculuğunu beraber yaparlar. Yanlarında da torunu. İsmet Paşa, torununa der ki:

- Git, Osman amcandan para iste.

O da gelip:

- Osman amca bana para verir misin? der.

- Ne yapacaksın oğlum parayı?

- Köylülere atacağım, sevinsinler, der.

Osman Bölükbaşı cevabı patlatır:

- Git dedeni at, bütün Türkiye sevinsin!..” (https://fikrabul.com/fikrabul/no/27140/en-guzel-erdalinonu-espirileri.htm).

"Bir gün başbakan ve muhalefet partisinin lideri aynı helikopterde gezerlerken dalmışlar muhabbete...

Muhalefet partisi lideri demiş:

- Ben buradan 30 milyon lira atsam 30 kişiyi sevindiririm.

- Ben buradan 50 milyon lira atsam 50 kişi sevinir.

Bunları duyan pilot da şöyle der:

- Ben buradan ikinizi atsam 70 milyon birden sevinir!..” (http://www.fikralarim.com/politik-fikralar).

Elektronik ortamda bir fikranın farklı versiyonlarına çokça rastlamaktadır. Bu durum çoğunlukla bir fıkranın olay örgüsü aynı bırakılarak yer, zaman ve kişilerinde yapılan bazı değişikliklerle yapılmaktadır. Sözlü kültürde farklı zaman ve kişilere ait fikraların bir tip etrafında toplanmaları veya benzer olay örgülerine sahip fikraların farklı kişiler etrafında anlatılması sıkça görülen bir niteliktir. Bu nitelik elektronik ortamda da devam etmektedir. Bu tür fikralar her şahıs, zaman ve mekâna uyarlanıp güncellenebilme niteliğine sahiptir:

“Amerika'da adamın biri işine giderken birden anormal bir trafiğin içine düşer; ama trafik bir santim bile kıpırdamamaktadır. Bir süre sonra aracının yan camına birisinin tıkladığını farkeder ve camı açar:

- Ne var acaba?

- Teröristler Bush'u yakaladılar. Eğer 1 milyar dolar verilmezse, üstüne benzin döküp yakacaklar.

- Haa! Şimdi anladım bu trafiği!..

- Ya işte onun için, herkesten biraz yardım topluyoruz.

- İnsanlar ne kadar veriyor ortalama olarak?

- Valla yaklaşı olarak beşer litre!..” (http://fikra.gen.tr/index.php?sayfa=mektup\&catid=14\&fikra no=2436). 
Elektronik kültür ortamında aynı fikranın yer ve kişi isimleri değiştirilerek dönüştürülmüş şekilleri bulunmaktadır. Başka bir versiyonunda olay Amerika'da değil İstanbul'da geçmekteyken, ABD Başkanı Bush'un yerini Türkiye’nin cumhurbaşkanı Recep Tayyip Erdoğan almaktadır. Bu değişikliklerin dışında olay hemen hemen aynı sözcüklerle anlatılmaktadır (https://www.uludagsozluk.com/k/komik-siyasi-f\%C4\%B1kralar/2/).

F1kralar “...cezalandırma, bir düşünceyi destekleme, sosyal eleştiri ve denetim mekanizması, dikkat çekme, az sözle çok şey anlatma, son sözü söyleme, kıssadan hisse kapma, gerilimleri yumuşatma, eğlendirme, güldürme ve rahatlatma...” (Öğüt Eker, 2006: 317) fonksiyonlarıyla özellikle siyasette çokça kullanılmaktadır. Bu tür fikralar yöneten-yönetilen ilişkilerinde görülen aksaklıkları/yanlışlıkları, mizah ve hiciv unsurları ile beraber anlatmaktadır. Siyasi fikralar, en keskin eleştirinin yapıldığı fikra türlerindendir. Birçok kişi yönetimi bıraktıktan sonra toplum tarafından unutulduğu halde, fikralara konu olanları, yaptıkları gerçek icraatlarından ziyade fikraya konu olmalarıyla unutulmaktan kurtulmaktadır. Halk, doğrudan eleştirmeye cesaret edemediği siyasi olay/kişileri fikralarla hicvetmiştir. Siyasi istikrarsızlığın arttığı dönemlerde bu tür fikralarda artış görülmektedir.

F1kralar sadece bugünün değil, geçmişten günümüze kadar siyasetin/siyasetçilerin halk tasavvurundaki imajını anlatmaktadır. Özellikle yakın dönem siyasetçileri ile ilgili bir hayli fikra bulunmaktadır. Siyasi fikralar halkın, devlet idaresindeki aksaklıklara karşı tepkisidir. Bu tür fikralarda insani ve toplumsal değerler yüceltilmektedir. Aşağıdaki fikra Türkiye'nin ilk/tek kadın başbakanı olan Tansu Çiller'in kişiliğinde bir siyasetçinin halkın tasavvurundaki imajını göstermektedir. 1990'lı yıllarda Türkiye'yi idare eden Tansu Çiller, günümüzde halk tarafından pek hatırlanmamakta; fakat fikralarda edindiği yerle yaşamaya devam etmektedir:

"Clinton, Yeltsin ve Çiller şeytanın huzuruna çıarlar. Hepsi şeytana dileklerini söyleyecek, o da onlara ne zaman gerçekleşeceğini söyleyecektir. İlk önce Clinton sorar:

- Amerika ne zaman her yönden tam olarak dünyanın hakimi olacak? der. Şeytan da:

- 50 y1l sonra, der.

Clinton ağlamaya başlar:

- Ben göremeyeceğim, ben göremeyeceğim...

Sıra Yeltsin'e gelmiştir. O da sorar:

- Rusya ne zaman eski gücüne kavuşacak?

Şeytan cevap verir:

- 100 y1l sonra.

Yeltsin de başlar ağlamaya:

- Ben göremeyeceğim, ben göremeyeceğim...

Sıra Çiller'e gelmiştir, o da sorusunu sorar:

- Ne zaman Türkiye'deki enflasyon düşecek?

Bu sefer şeytan ağlamaya başlar:

-Ben göremeyeceğim, ben göremeyeceğim!.. (https://fikraburda. wordpress.com /category/politika-fikralari/). 
Tansu Çiller'in ülkeyi idare ettiği dönemin en büyük sorunlarından biri ekonomik istikrarsızlıktır. Halk, ekonomik sorunların en büyük sebebi olarak gördügü yüksek enflasyona ve enflasyonun da en büyük nedeni olarak gördügü siyasetçinin ülkeyi yanlış idare etme şekline karşı tepkisini fikralarla dile getirmiştir.

“Özellikle demokratik toplumlarda siyasetçi, toplumu yönlendirmekten çok toplum tarafından yönlendirilmektedir. Siyasetçi toplumun aynasıdır; çünkü siyasetçi profili halkın tercihlerine göre şekillenmektedir" (Akyüz, 2009: 98). Bu bakımdan fikralarda sıkça dile getirilen yolsuzluk sorununun kaynağını sadece siyasetçide aramak eksiktir. Yolsuzluğun/ usulsüzlüğün bir yaşam biçimine dönüştüğü toplumlarda, farklı bir siyasetçi ve siyaset anlayışı beklenmemelidir. Bundan dolayı fikralarda siyasetçilere yönelik tüm eleştiriler, aslında topluma yapılmıştır. Aşağıdaki fikra sadece bir siyasetçinin değil, aynı zamanda toplumun ahlaki yapısını gösteren bir örnektir:

"Bir gün bir karı-koca, 18 yaşındaki oğullarını bir testten geçirmeye karar verirler. Bir masanın üstüne bir miktar para, bir dini kitap ve bir şişe şarap koyarlar. Çocuk din kitabını seçerse din adamı, parayı seçerse işadamı, şarabı seçerse de işe yaramaz tembel biri olacaktır bu testin sonunda. Gizli bir yere saklanıp olacakları merakla beklemeye başlarlar. Bir süre sonra oğlan gelir. Parayı cebine koyar. Din kitabını görüp sayfalarını karıştırır ve onu da alır. Sonra şarabı görüp hepsini içer. Babası eşine dönüp der ki:

- Hanım bizim çocuğun durumu sandığımızdan da beter çıktı, galiba politikacı olacak!..” (http:// www.fikralarim.com/politik-fikralar).

"Siyasetin pis, kaygan, kaypak, bulaşılmaması gereken bir olgu olarak algılanmasına karşın siyasetçi toplumda gittiği her yerde saygı görür, topluluklarda sözü dinlenir, önünde ceket iliklenir, mitinglerine binlerce kişi katılır" (Akyüz, 2009: 103). Bu durum toplumun fikralarda yarattığı siyasetçi tipi ile davranışları arasındaki çelişkiyi göstermektedir. Toplum bir taraftan siyaset ve siyasetçiye mesafeli yaklaşırken, öte taraftan ona saygı duymaya, onu kendisine önder olarak kabul etmeye devam etmektedir. Türk toplum hafizasında siyaset kurumu ve siyasetçi öyle olumsuz bir imaja sahiptir ki bu imaj zaman zaman önyargıları da beraberinde getirmektedir:

"Bir ülkede bir bakan, kendisini gazetecilere hiç sevdirememişti. Ne yapsa makbule geçmiyor, basın her gün kendisiyle uğraşıyordu. Nihayet 'Öyle bir şey yapayım ki, gazeteciler mat olsun' diye düşündü ve ilan etti:

- Pazar günü saat 10.00 'da denizin üzerinden yürüyerek geçeceğim.

Pazar sabahı saat 10.00 'da tüm basın mensupları toplandılar orada. Bakan geldi ve elinde bastonuyla denizin üzerinde yürümeye başladı. Karşı kıyıya kadar da yürüdü, geçti. Herkesin gözleri dehşetle açılmıştı. Fakat ertesi günü tüm gazetelerde şu başlık okundu: ‘Bakan, yüzme bilmiyor!..” (http://www. fikralarim.com/politik-fikralar).

Siyaset en doğru argümanı öne sürenin kazandığı değil, seçmenlerini en iyi biçimde ikna edenlerin kazandığı bir sistemdir. Modern demokrasilerde siyaset ikna edici konuşmalara dayanmaktadır. Siyasetçilere yapılan eleştirilerden biri de samimi olmamalarıdır. "Demokratik siyasetin yalana imkân tanıdığg, ikiyüzlülük üzerine bina olduğuna dair suçlamaların berisinde, bu sistemin bir yandan dürüst ve açık bir siyasal uzam sağlama iddiasına rağmen ikna ve karşılıklı bağımlılık üzerine yükselen ilişkiler nedeniyle ikiyüzlü siyasal davranışı teşvik etmesi bulunur" (Özden, 2018: 54). Bir siyasetçiden bir taraftan dürüst ve açık bir söylem/ 
eylem beklenirken, diğer taraftan onun seçmenini ikna etmesi istenmektedir. Farklı çıkarlara sahip kişilerin birlikte yaşadığı bir toplumda, bu durum bir paradoks oluşturmaktadır. Toplumun siyaset kurumundan beklentisi kişisel çıkarlara dayalı olduğu sürece, bu paradoks devam edecektir. Kamusal çıkarın kişisel çıkarların önüne geçmesi, siyaset kurumundan ahlaki beklentileri anlamlı hale getirecektir. Karşılıklı bağımlılık esasına göre şekillenen siyaset, ikiyüzlülüğü zorunlu hale getirmektedir. "Farklı çıkarlara, arzu ve isteklere sahip bir dinleyici kitlesinin sınamasına tabi olan siyasal aktör bu durumda, muhataplarını ikna edebilmek için kendini olduğundan daha iyi ya da daha kötü göstermelidir" (Özden, 2018: 56).

Boratav, bir zümrenin başka bir zümreyi alaya alıp küçültmek amacıyla ürettiği fikralardan söz ederken “... bu tip hikâyelerin pek çoğunda 'alay konusu' sanılan kişinin 'alay eden' durumunda olduğu... o anlatıları yaratan ve yayanların da, onlarda anlatılan kişilerin kendileri oldukları çok kez görülmüş bir olgu" (1999: 93) olduğunu belirtir. Buna göre bir siyasi kişilik ve siyasetin genel olgusunu konu edinen bir fikra, onu yaratan milletin kendisini yansıtmaktadır. Bir toplumun tutum ve davranışları, duygu ve düşünceleri siyasetçi tipinde kendisini görünür hale getirmektedir. Bir fikra, ne kadar vahşi bir olayı anlatırsa anlatsın, yapısı gereği içindeki tiksindirici, ürpertici, vahşet verici olayı gülümseten, iyi niyetli bir tenkit ve mizaha dönüştürebilmektedir.

Sözlü kültürde belli bir dinleyici grubuna karşı çoğu zaman eğlenmek/gülmek için anlatılan fikra, ikincil sözlü kültür ortamında bağlamının değişimine bağlı olarak üstlendiği işlevlerin farklılığıyla karşımıza çıkmaktadır. "Özellikle çağdaş kültürün ürettiği fikralarda ülke politikasının, siyasetçilerin, spor ve sporcuların, medyada gündem oluşturan isimlerin, yerleşmiş âdetlerin eleştirisine sıkça rastlanır” (Buğra, 2005: 95). Halk hafızasında, bir siyasetçinin halktan tek isteği vardır: oy almak. Siyasetçinin bunun dışında halkla bir alışverişinin olmadığ düşünülmektedir. Bir dönemin renkli siyasi kişiliği Erdal İnönü ile ilgili aşağıdaki fıkra, bu düşünceyi mizahi açıdan anlatmaktadır:

“Seçmenlerden biri seçim otobüsünün önüne atılır ve Erdal Bey’e hitaben:

- Ölürüm yoluna, diye haykırır. Erdal Bey cevap verir:

- Dur, ölme. Bir oy, bir oydur!..” (https://fikrabul.com/fikrabul/no/27140/en-guzel-erdal-inonuespirileri.htm).

F1kralar elektronik ortamda dönüştürülmüş, kitleleri etkileyen tüketim malzemesine çevrilmiştir. "Fıkra" adını taşıyan sakızın halk arasında rağbet görmesi, halk ürünlerinin tüketim aracı olarak pazarlamada kullanıldığının ve ürünün satışlarında olumlu etkide bulunduğunun açık bir göstergesidir. Halkın hafızasında bulunan "fıkra" kodu, ürünün pazarlanmasını kolaylaştırmaktadır. Fıkralar sanal dünyada hayatını sürdürürken, sözlü kültür ürününün unutulmasını engellemiş; türün yeni ürünlerle zenginleşmesini sağlamıştır.

Sözlü gelenekte fikra herhangi bir neden yokken, durup dururken anlatılmaz. Belli bir olaya bağlı olarak, anlatılmak istenen düşünceyi daha etkili kılmak amacıyla anlatılır. Elektronik ortamda ise fikra, bu bağlamından koparılmıştır. Anlatılan fıkralar, çoğu zaman belli bir olaya bağlanmadan, zaman/mekân unsurlarından uzaklaştırılmıştır. Bağlamsal değişim veya elektronik ortamda bağlamından uzaklaştırılan fikra, sözlü kültürdeki işlev ve etkinliğini de yitirmiştir. Bu durum, fikranın daha geniş kitlelere daha hızlı biçimde ulaşmasını sağlarken; bağlama ait bilgilerin bulunmaması, icra esnasındaki etkili ve anlamlı aktarımı ortadan kal- 
dırmıştır. Sözlü geleneğin canlı, dinamik, etkin ürünü; elektronik ortamın cansız, statik bir türüne dönüşmüş̧ür. "Bir fikra, internet ortamında anlatıldığında anlatıcı, dinleyicinin yaşı, cinsiyeti, etnik yapısı, eğitim durumu, mesleği vb. hakkında bilgi sahibi olmadığından anlatımını dinleyiciye ya da dinleyicilere göre şekillendirememektedir. Fıkra her yaştan, cinsiyetten, meslekten kişiye aynı anlatımla ulaşmaktadır" (Çalış, 2010: 4).

İnternet ortamında zaman ve mekân unsurları ortadan kalkmakta, fikranın anlamı anlatıcıdan ziyade okuyucu tarafından belirlenmektedir. "Bir anlamda sözel ortamdan yazılı ortama geçirilen anlatılarda, yazının koruyuculuğu ve hapsediciliğiyle korunan çeşitlenmenin tutarlılığından söz edebilirken, internette yayılan ve emaillerle aktarılan fikraların çeşitlenme sınırları belirlenemez konuma gelmiştir" (Gür, 2007: 94).

Aydemir, milletvekilleri tarafından meclis kürsüsünde anlatılan Temel fikralarını incelerken, vardığ 1 sonuçlardan birini "Partilerin kendilerini tanımladıkları kavramlar fıkralarda söz konusu edilebilmekte; bu da, karakterler etrafinda partinin siyasal görüşünü temel alan kutuplaşmalar meydana getirmektedir" (2007: 86) şeklinde ifade etmektedir. Elektronik ortamdaki siyasi fikralarda da seçmen grubunun siyasi kişilikleri tanımlama biçimleri yer almakta; partilerin siyasal görüşlerini temel alan kutuplaşmalar, seçmen-siyasetçi merkezinde meydana gelmektedir.

"Günümüzde anlatılan fikralardan geleneksel bağı olanların ya karakteri/kişisi değiştirilmekte ya da o eski yani geleneksel fikralar yeni şartlara göre uyarlanıp farklı bir renkle sunulmaktadır. Mizah dergilerinde, bir ara pek moda olan siyaset adamlarının adına bağlı olarak oluşturulan kitaplarda, her tür gazetenin -siyasi, spor, magazin, vb.- ilgili köşelerinde yer alan fikralardan bazıları âdeta her iki tipin, geleneksel tip ile modern tipin karışımı gibidir" (Sakaoğlu, 2013: 71). Sözlü ve yazılı kaynaklarda yer alan bazı fikraların elektronik ortamda bazı güncellemeler yapılarak yer aldığı görülmektedir. Bu tür fikralar, aynı olay örgüsü etrafında bazı değişim/dönüşümlerle, yeni zamana/mekâna uyarlanmıştır:

"Yolda giderken, birden ayağı kayıp düşen adama arkasından gelen yardım etmiş, kaldırmış. Düşen adam teşekkür ettikten sonra bakmış karşısında RP Genel Başkanı Necmettin Erbakan... Yine de kendini kibarlık etmeye zorunlu hissetmiş:

- Bu iyiliğinize nasıl karş1lık verebilirim? diye sormuş. Erbakan:

- Lafı mı olur muhterem kardişim, bizim partiye oy verirsiniz ödeşmiş oluruz, deyince düşen adam dayanamamış:

- Beyefendi, ben düşünce yalnızca kıçımı çarptım, kafamı değil” (Tan'dan akt. Elaltuntaş, 2018: 284).

Bu fikra sözlü gelenekte meydana gelmiş, sonradan yazıya aktarılmıştır. Aynı fikra elektronik kültür ortamında bir kişiye (Necmettin Erbakan'a) bağlı olmaktan çıkarılarak “iktidar partisinin bir üyesi” şeklinde genel bir iktidar eleştirisine dönüştürülmüştür (https://www. fikra.in/politik-fikralar/desme.html).

"Çoğu fikranın konusu, idare eden sınıf ile idare edilen sınıf (halk) arasında geçer. Yöneten ve yönetilen arasında yaşanan ve daha çok yönetilen grubun yanında olup onların türlü sıkıntılarını dile getiren olaylar her zaman için insanların ilgisini çekmiştir. Halk doğrudan söyleyemediği, çekindiği, korktuğu şeyleri fıkra kahramanının ağzından söylemektedir" (Şimşek, 2015: 199). Bu özelliğiyle fikralar, konusunu gerçek hayattan almakta ve toplumun aksayan yönlerini tenkit etmektedir. 
İnsan-iktidar ilişkileri tarihin ilk dönemlerinden itibaren, insanların hayatını şekillendiren/yönlendiren önemli sorunlardan biri olmuştur. Her dönemde insanların iktidara karş1 bakışları/tutumları farklılaşmıştır. Siyasal iktidar zaman zaman gücünü sürdürmek/attırmak ve meşrulaştırmak için, tanrısal iktidardan destek almıştır. Siyasal iktidarın tanrısal iktidardan güç alması, eylemlerini olağanlaştırma, tartışmasız hale getirme çabasının sonucudur. Ortaya konulan dokunulamaz referans, itirazı/eleştiriyi önlemektedir. Fıkralar da tam olarak burada ortaya çıkmaktadır. Fıkra dokunulmayana dokunmaya çalışır, kendi söylemiyle yeni bir düzen talep eder. Fıkralar aynı zamanda iktidar ile halk arasındaki mesafenin artışının da bir göstergesidir. Bu mesafe arttıkça halk, doğal yollardan isteklerini iktidara iletememekte, bu noktada fikraların etkin gücünden yararlanılmaktadır. Burada fikraların siyasal anlamda halkın bütünleşmesini sağlayan işlevi ön plana çıkmaktadır. "İktidar olana karşı üretilen fikraların sadece mizah yönünün vurgulanmış olması, fikraların halk olma ve bütünleşme anlamında gerçekleştirdiği söylemsel bütünlügüün 'dar' bir alana sıkıştırılarak etkisizleştirilmesine yol açabilir” (Uygun, 2012: 75). Bu yönüyle fikralar, içerdikleri mizahla beraber, halkın bir düşünce etrafında bütünleşmesini sağlayan etkin kültürel araçlardan biridir.

Siyasal fikralar, halkın siyasi iktidara karşı doğrudan veya ulaşma imkânı olmadığından iletemediği tenkitlerinin/mesajlarının duyurulmasını, böylece halkın aynı duygu, düşünce etrafında bir araya gelmesini sağlayan, aynı bütünün parçası oldukları hissini veren unsurlardan biridir. Halk ürettiği/aktardığ 1 ve bağlamına göre değiştirdiği/dönüştürdüğü siyasi fikralarla, pasif bir izleyici/dinleyici olmaktan öte etkin bir katılımc1, müdahil pozisyonuna geçmektedir. Fıkra mutlak iktidarın "ulaşılamazlık/dokunulamazlık" niteliğine ulaşmayı/dokunmayı mümkün hale getirmektedir. İktidar karşısında halk tarafından hissedilen acizlik ve korku, üretilen fikralarla oluşturulan birliktelik duygusuyla aşılmaya çalışılmaktadır. Buradaki birliktelik bilinçli olmaktan ziyade, kendiliğinden halkın ortak bir değer olarak oluşturduğu fikralar etrafinda meydana gelen bir birlikteliktir.

Mizah toplumun sosyal, siyasal, kültürel, ekonomik vb. alanlarda en fazla baskı altında olduğu, bu baskılara karşı doğrudan söylemlerin geliştirilemediği veya geliştirildiğinde çeşitli baskılarla karşılaşılacağı korku dönemlerinin önemli bir düşünce aracıdır. Halk bu yolla, çeşitli şekillerde karşılaşacağı ceza ve yasaklardan kurtulmakta, gizli bir protesto gerçekleştirmektedir. "Özellikle siyasal iktidarın, tanrısal kuvvetin iktidarını kullanarak kendisini var etmesi ve bu verili kuvveti ardına alarak halka karşı yaptığı olumsuz edimler, halkın güvenemediği iki soyut bütünlüğü beraberinde getirir. Bu güvensizlik ve dokunamama nedeniyle halk 'son çare' olarak fikralar yoluyla, kendiliğinden bir karşı duruş sergilemiş olur” (Uygun, 2012: 81-82). Aşağıdaki fikra, halkın son çare olarak başvurduğu bu yolun ne derece etkin olduğunu da göstermektedir:

"Meydanlarda atıp tutan politikacılarımızdan biri hacca gitmiş. Hac vazifesini yerine getirirken sıra gelmiş şeytan taşlamaya... Eline almış taşları, iç huzuru ile başlamış Allah ne verdiyse şeytan taşlamaya.

Ama o da ne? Taşın düştüğü yerden bir feryat, bir yakınma yükseliyor ki sormayın gitsin... Şeytan hem ağlıyor hem de bir şeyler söylüyor. Bizim politikacı merak etmiş, kulak kabartmış. Şeytan:

- Olur mu böyle, olur mu? diyormuş, kardeş kardeşi vurur mu?" (http://www.fikralarim.com/politik-fikralar). 
“Mizah çok zaman, söylenemeyenleri söylemenin, kutsalın üzerindeki göz boyayıcı örtüyü almanın, iktidar sahiplerini eleştirmenin en uygun tonu olarak kabul edilir" (Uslu, 2005: 109). Mizahta, ciddi söyleyişin yaratacağı rahatsızlığgn/gerilimin yumuşatılması amaçlanmaktadır. Gülmede kişileri memnun eden psikolojik bir değişiklik bulunmaktadır. Buradaki psikolojik değişiklik, kişiye zevk vermektedir. Özellikle kişi kendisini güvende hissediyorsa gülmeden daha çok memnuniyet duyar. Morreal'in ifadesiyle "gülme psikolojik bir değişiklikteki memnuniyetin ifadesidir” (1998: 102). Recep Tayyip Erdoğan ile Abdullah Gül, Türk siyasetinin önemli kişilerindendir. Recep Tayyip Erdoğan'ın İngilizce bilmediğini anlatan aşağıdaki fıkra, dinleyenlerin psikolojik olarak zevk almalarını sağlarken, fikrada yer alan kişileri de güldürmekte, onları rahatsız edecek durumu ortadan kaldırmaktadır:

"Recep Tayyip Erdoğan ile Abdullah Gül konuşuyorlarmış. Erdoğan:

- Abdullahcığım İngilizce'n iyi mi?

Gül:

- Yeterince.

Erdoğan:

- Bir cümle var da onu Türkçe'ye çevirir misin?

Gül:

- Bilirsem tabii ki.

Erdoğan:

- 'I don't know' ne demek?

Gül:

- Bilmiyorum.

Erdoğan:

- 'Yapma be Abdullah!.. Sen de mi bilmiyorsun? Bugün kime sorduysam bilmiyorum dedi” (http:// www.fikradeposu.com/recep-tayyip-erdogan-fikralari/bilmiyorum/\#more-3899).

Yabancı dil bilmek, birçok meslek grubunda olduğu gibi, siyaset adamlarında da aranılan niteliklerden biridir. F1krada "bilmiyorum" fiili muhatabın sadece yabancı bir dil bilmediğini değil, aynı zamanda kinayeli biçimde dinleyici kitlesinin bilinçaltında mevcut siyasetçiye karşı genel kanaati de göstermektedir. Fıkrada asıl anlatılmak istenen siyasetçinin, siyaseten istenilen ehliyete sahip olmamasıdır. Bir siyasetçide olma[ma]sı gereken bir niteliği yukarıdaki fikra kadar bir taraftan güldürürken diğer taraftan düşündürerek, kırmadan/dökmeden/ gücendirmeden ifade edecek başka bir tür var mıdır?

Yukarıda ifade edilen nitelikleriyle fikra, halkın siyaset kurumu ve siyasetçi eleştirisinde en etkili araçlardan biridir. Eleştirinin sert ve yıkıcı üslubunu hoşgörüye dayalı yapıcı bir niteliğe çeviren fikra, gergin ortamları gülen/güldüren yüzüyle yumuşatmaktadır. William R. Bascom (2010: 78-81) folklorun dört işlevinden söz eder: a. eğlence, b. kültürün, ritüel ve kurumların onaylanması, c. eğitim, d. kabul edilmiş davranış örüntülerini sürdürme. Fıkraların siyasetteki kullanımlarına bakıldığında eğlence işlevinin dışarıdan baskın gibi görünmesine rağmen, bu işlevin diğer işlevleri yerine getirmek için bir maske gibi kullanıldığg görülmektedir. Siyasi fikralar halkı güldürür; ancak temel/tek oluşturulma/anlatılma amaçları eğlence değildir. Siyasi fikralar, siyaset kurumunda olması beklenen doğruluk, adalet, eşitlik, hizmet 
gibi kültürel ve ahlaki değerlerdeki çürümeyi/yozlaşmayı anlatmaktadır. Bu değerler, halkın kabul ettiği önemli davranış örüntüleridir. Toplumsal bellekte bir insan kitlesini millet yapan, halka dönüştüren değerlerin devamı toplumun geleceğinin devamı için gereklidir. Siyasetteki yanlışlıklar/yozlaşmalar dile getirilirken, hem siyaset kurumuna hem de halka çeşitli mesajlar gönderilerek her iki kitle de eğitilmektedir. Bundan dolayı bir siyasi fikra, Bascom tarafından ifade edilen son üç işlevi, eğlence işlevi altında daha baskın biçimde yerine getirmektedir. Bu yönüyle eğlence, siyasi fikralarda vardır; ancak diğer işlevlere nazaran belki de en son aranılacak işlevdir. Bir kişinin bir siyasi fikrayı anlatmadaki ilk/temel amacı, insanları eğlendirmek değil; onlara yolunda gitmeyen bir şeyleri haber vermektir.

\section{Sonuç}

Radyo, televizyon, bilgisayar gibi elektronik iletişim araçları, halk ürünlerinin sözlü ve yazılı kültür ortamlarına göre daha geniş kitlelere hızlı biçimde ulaşmasını sağlayan yeni üretim ve aktarım ortamlarıdır. F1kralar da sanal ortamda en fazla kullanılan folklor türlerinden biridir. Bir tarafta sadece fikra türünü içeren onlarca site yer alırken, diğer tarafta farklı amaçlarla kurulmuş sitelerde çok sayıda fikraya rastlanmaktadır. Mevcut siteler, hem sitenin kurucuları hem de siteyi takip eden kullanıcılar tarafından eklenen yeni fikralarla her geçen gün arşivlerini zenginleştirmektedir. Bu fikraların bir kısmı sözlü ve yazılı kültür ortamında anlatılan fikraların yeni bağlama uyarlanmış şekilleriyken, bir kısmı da yeniden yaratılan fikralardır. Sanal âlemde meydana getirilen siyasi fikralar, bulunulan zamana/mekâna ve sosyoekonomik yapılara uygun biçimde kendisini güncellemektedir. Farklı sitelerde benzer fikralara rastlanmakla beraber, aynı fikranın farklı versiyonları da zengin bir fikra kaynağını oluşturmaktadır. Elektronik ortamda genel siyasi olaylardan özel siyasi kişilere kadar çok çeşitli fikralar dolaşımdadır.

Her kültür ortamı sahip olduğu bağlam ve işleve göre ürünlerini şekillendirir. Bu bakımdan yeni kültür ortamının ürünleri de bağlam ve işlev farklılığının sonucunda yeni ürünler ortaya koymaktadır. Yönetenler, fikralar vasıtasıyla halk tarafından eleştirilmektedir. Bu fikralarda siyaset adamları, küçük düşürücü/istenilmeyen durumlara sokularak cezalandırılmaktadır. Burada fikra tenkitten öte bir yaptırım unsuru olarak etkin bir işleve dönüşmektedir. Halk iktidara karşı bir tepki oluşturmuş, bu tepki fikra söylemiyle kitleselleştirilmiştir. Siyasal eleştiri halkı bir olay karşısında eyleme geçirmiş, bir araya getirmiştir. Tanrının ediminin/gücünün dahi eleştirildiği/ sorgulandığı fikralarda, siyasi iktidarların bundan pay alması gayet doğal karşılanmalıdır.

Sözlü geleneğin fikra anlatıcısı, elektronik kültür ortamında yerini internet kullanıcısına bırakmıştır. Sanal âlemde internetin kendisi anlatıcı olurken, takipçiler/kullanıcılar dinleyici vazifesi görmektedir. Sözlü gelenekte farklı zaman ve kişilere ait fikraların bir tip etrafında toplanmaları veya benzer olay örgülerine sahip fıkraların farklı kişiler etrafında anlatılması, elektronik ortamda da devam etmektedir. Elektronik kültür ortamında aynı fikranın yer ve kişi isimleri değiştirilerek dönüştürülmüş şekilleri bulunmaktadır. Birçok siyasetçi iktidarı bıraktıktan sonra zamanla toplum tarafindan unutulmaktadır. Ancak fikralara konu olanları, halkın hafızasında varlığını korumaya devam etmektedir. Bu niteliğiyle fikralar, iktidarları sonrasında siyasetçilerin olumlu/olumsuz nitelikleriyle anılmaya devam etmelerini sağlayan etkin birer araçtır. 
Siyasi istikrarsızlığın arttığı dönemlerde siyasi fikralarda artış görülmektedir. Fıkralarda siyasetçilere yönelik tüm eleştiriler, aynı zamanda onu yaratan milletin kendisini yansıtmaktadır. Bir toplumun tutum ve davranışları, duygu ve düşünceleri siyasetçi tipinde kendisini görünür hale getirmektedir. Fıkralar iktidar ile halkın birbirinden uzaklaştığının da bir göstergesidir. Halk doğal yollardan isteklerini iktidara iletememekte, bu noktada fikraların etkin gücünden yararlanmaktadır. Halk ancak fikralarla mutlak iktidara ulaşabilmekte/dokunabilmektedir. Halk fikra ile söylenemeyenleri söylemekte, kutsalın üzerindeki örtüyü kaldırmaktadır. Sonuç olarak fikra, halkın siyaseti/siyasetçiyi eleştirisindeki sert ve yıkıcı üslubunu hoşgörüye dayalı yapıcı bir niteliğe çevirerek, gergin ortamları gülen/güldüren yüzüyle yumuşatmaktadır.

\section{Kaynaklar}

Akyüz, Ü. (2009). Siyaset ve ahlak. Yasama dergisi, 11, 93-129.

Aslan, F. (2011). Sanal kültür ortamında güncellenen Nasreddin Hoca fikraları. Turkish Studies -International Periodical for the Languages, Literature and History of Turkish or Turkic, 6/4, 39-60.

Aydemir, U. (2007). Meclis kürsüsünden temel fikraları: Bağlam merkezli halkbilimi kuramlarıyla bir kültürel analiz denemesi. Millî Folklor, 75, 76-87.

Ayık, C. (2016). Kutadgu bilig ve siyasetname'de ahlak siyaset ilişkisi. Yüksek Lisans Tezi. Hitit Üniversitesi Sosyal Bilimler Enstitüsü Felsefe ve Din Bilimleri Anabilim Dalı.

Bascom, W. R. (2010). Folklorun dört işlevi. (çev. F. Çalış). Halkbiliminde kuramlar ve yaklaşımlar 2. (yay. hzl. M. Ö. Oğuz-S. Gürçayır). Ankara: Geleneksel. 71-86.

Boratav, P. N. (1999). 100 soruda Türk halk edebiyatı. İstanbul: Gerçek.

Boratav, P. N. (2017). Halk dilinde hiciv ve mizah. Folklor ve Edebiyat II. Ankara: BilgeSu. 303-307.

Buğra, G. (2005). Sözlü kültürden yazılı kültüre "fikra"nın "pazarlama” sektöründe dönüşümü ve fonksiyonlar1. Millî Folklor, 67, 94-97.

Çalış, H. Sözlü kültür ortamından internet ortamına fikralar. 4. Halk Kültürü Alan Araşstırmaları Semроzуити, 8-10 Mart 2010. (http://turkoloji.cu.edu.tr/HALKBILIM /hikmet_calis_sozlu_kultur_ ortami_internet_fikra.pdf. Erişim Tarihi: 04.02.2019).

Dundes, A. (1998a). Doku, metin ve konteks. (çev. M. Ekici). Millî Folklor, 38, 106-119.

Dundes, A. (1998b). Halk kimdir. (çev. M. Ekici). Millî Folklor, 37, 139-153.

Ekici, M. (2008). Geleneksel kültürü güncellemek üzerine bir değerlendirme. Millî Folklor, 80, 33-38. Elaltuntaş, Ö. F. (2018). Türk kültüründe siyaset-halk edebiyatı ilişkisi. Ankara: Sonçağ.

Gür, N. (2007). Sanal anlatıda eksik kılınmış bir portre: Temel ve hikâyesi. Millî Folklor, 75, 91-94.

Kafesoğlu, İ. (2012). Türk millî kültürü. İstanbul: Ötüken.

Morreal, J. (1998). Gülmede yeni bir teori. (çev. M. Ekici). Millî Folklor, 38, 88-105.

Ögüt Eker, G. (2006). Gelenekten geleceğe halk edebiyatı. Türk halk edebiyatı el kitabı. (ed. M. Ö. Oğuz). Ankara: Grafiker. 315-329.

Özdemir, N. (2002). Türkiye'de siyasal parti kültürü. Millî Folklor, 56, 53-74.

Özden, Ö. (2018). Yalan, yemin ve siyaset: "Hakikat-sonrası" siyasete ilişkin bir soruşturma. Doktora

Tezi. Ankara Üniversitesi Sosyal Bilimler Enstitüsü Siyaset Bilimi ve Kamu Yönetimi (Siyaset Bilimi) Anabilim Dal1.

Sakaoğlu, S. (2013). Geleneksel fikra-modern fikra. Millî Folklor, 97, 70-75. 
Şimşek, E. (2015). Türk halk edebiyatı anlatı türleri içerisinde fikraların yeri. Akra Kültür Sanat ve Edebiyat Dergisi, 6, 195-234.

Tan, N. (1999). Folklorumuzda politik fikralar. Ankara: Folklor Araştırmaları Kurumu.

Tekin, T. (2010). Orhon yazıtları. Ankara: Türk Dil Kurumu.

Tufan, Y. (2007). "Uyumsuzluk kuramı" bağlamında sanal ortamda temel fikraları. Millî Folklor, 75, 108-112.

Uslu, M. F. (2005). Fıkralarda dinsel iktidar örüntüsünün kırılması. Millî Folklor, 67, 109-114.

Uygun, İ. (2012). Tanrısal ve siyasal iktidara karşı üretilen fikralarda "dokunma" işlevi. Millî Folklor, 96, 74-83.

Yıldırım, D. (1998). "Fıkra türü”. Türk Bitiği. Ankara: Akçağ. 221-231.

\section{Elektronik kaynaklar}

http://fikra.gen.tr/index.php?sayfa=mektup\&catid=14\&fikra_no=2436 (Erişim Tarihi: 14.01.2019).

http://www.erenet.net/fikralar.php?op=kategoriler\&kategoriid=7 (Erişim Tarihi: 14.01.2019).

http://www.fikracim.com (Erişim Tarihi: 15.01.2019).

http://www.fikradeposu.com (Erişim Tarihi: 16.01.2019).

http://www.fikralarim.com/siyasetciler.html (Erişim Tarihi: 14.01.2019).

http://www.internethaber.com/yildirim-akbulut-fikralari-foto-galerisi-1171061.htm?page=11 (Erişim

Tarihi: 15.01.2019).

https://fikrabul.com/fikrabul/no/27140/en-guzel-erdal-inonu-espirileri.htm (Erişim Tarihi: 16.01.2019). https://fikraburda.wordpress.com/category/politika-fikralari/ (Erişim Tarihi: 15.01.2019).

https://www.fikra.in/politik-fikralar/desme.html (Erişim Tarihi: 04.02.2019).

https://www.sihirlihikaye.com/siyasi-fikralar.html (Erişim Tarihi: 14.01.2019).

https://www.uludagsozluk.com/k/komik-siyasi-f\%C4\%B1kralar/ (Erişim Tarihi: 14.01.2019). 